УДК 577.15:58.085.089:636.1.028

DOI 10.32900/2312-8402-2021-125-47-59

\title{
EVALUATION OF OXIDATIVE STRESS BIOMARKERS IN EQUINE ERYTHROCYTES AFTER IN VITRO TREATMENT WITH LEAF EXTRACT OF THYMUS PULEGIOIDES L. (LAMIACEAE)
}

\author{
Tkachenko H., Doctor of Biological Sciences \\ https://orcid.org/0000-0003-3951-9005 \\ Kurhaluk N., Doctor of Biological Sciences \\ https://orcid.org/0000-0002-4669-1092 \\ Institute of Biology and Earth Sciences, Pomeranian University in Słupsk, Poland \\ Honcharenko V., Ph.D. https://orcid.org/0000-0001-6888-2124 \\ Nachychko V., Ph.D. https://orcid.org/0000-0001-6756-2823 \\ Prokopiv A., Ph.D. https://orcid.org/0000-0003-1690-4090 \\ Ivan Franko National University of Lviv, Ukraine \\ Aksonov Ie. https://orcid.org/0000-0002-6292-7819 \\ The Institute of Animal Science NAAS, Kharkiv, Ukraine
}

In line with our previous study, we continue to evaluate the antioxidant potential of four species and one interspecific hybrid of the Thymus genus sampled in the Western part of Ukraine on the equine erythrocyte model. Therefore, in the present study, the oxidative stress biomarkers [2-thiobarbituric acid reactive substances (TBARS), carbonyl derivatives content of protein oxidative modification, total antioxidant capacity (TAC)], as well as HCl-induced hemolysis in the equine erythrocytes, was used for assessing the antioxidant activity of extract obtained from the leaves of Thymus pulegioides L. in dose $5 \mathrm{mg} / \mathrm{mL}$. Leaves of Th. pulegioides were collected among grass nearby land parcels (Syvky village, Bilohirya district, Khmelnytsky region, Ukraine; $N$ $50^{\circ} 02^{\prime} 02,8^{\prime \prime}$, E 26 $6^{\circ} 14^{\prime} 13,9^{\prime \prime}, 306 \mathrm{~m}$ a.s.l.). Equine erythrocyte aliquots were used in the study. For positive control (blank), phosphate buffer was used. After incubation of the mixture at $37^{\circ} \mathrm{C}$ for 60 mins with continuous stirring, samples were used for the biochemical assays. Results of the current study revealed that the extract obtained from leaves of Th. pulegioides $(5 \mathrm{mg} / \mathrm{mL})$ has a mild cytotoxic activity on the equine erythrocytes increasing the level of lipid peroxidation biomarker and hemolysis rate. The investigation also revealed that this extract exhibited hemolytic activity. These findings suggest the use of Th. pulegioides extract in dose $5 \mathrm{mg} / \mathrm{mL}$ as a source of prooxidant compounds and warrant further studies to evaluate their therapeutic potential. The aldehydic and ketonic derivatives level, as well as total antioxidant capacity, was nonsignificantly altered after in vitro incubation with an extract obtained from leaves of Th. pulegioides. Screening of Thymus species for other biological activities including antioxidant activities is essential and may be effective for searching the preventive agents in the pathogenesis of some diseases as well as prevention and treatment of some disorders in medicine and veterinary.

Keywords: Thymus pulegioides L., leaf extract, equine erythrocytes, lipid peroxidation, oxidatively modified proteins, total antioxidant capacity, hemolysis

The genus Thymus (Lamiaceae) comprises about 214 species throughout the world, mainly found in North Africa, Europe, and the temperate Asia zone. This genus of plants possesses a variety of activities including antimicrobial, antioxidant, anti- 
inflammatory, cytotoxic, analgesic, and antidiabetic, traditionally used in folk medicines [16]. Several studies have evaluated the potential therapeutic uses of pharmaceuticals, nutraceuticals, and cosmeceuticals based on thymol for the treatment of disorders affecting the respiratory, nervous, and cardiovascular systems. Moreover, this compound also exhibits antimicrobial, antioxidant, anticarcinogenesis, antiinflammatory, and antispasmodic activities, as well as a potential as a growth enhancer and immunomodulatory [25]. The Thymus genus comprises numerous species that are particularly abundant in the West Mediterranean region. As Afonso and co-authors (2020) noted, many of these species are a rich source of bioactive compounds, including phenolic compounds, i.e. rosmarinic acid, salvianolic acids, and luteolin glycosides, able to render their potential applications in a range of industrial fields [1]. Thymol (10$64 \%$ ) is one of the major constituents of essential oils of thyme (Thymus vulgaris L., Lamiaceae), a medicinal plant with several therapeutic properties [25].

Thymol, chemically known as 2-isopropyl-5-methylphenol, has been used in traditional medicine for centuries exhibiting various pharmacological properties including antioxidant, free radical scavenging, anti-inflammatory, analgesic, antispasmodic, antibacterial, antifungal, antiseptic, and antitumor activities [22]. It is one of the main compounds of thyme essential oil. Both thymol and thyme essential oil have long been used in traditional medicine as an expectorant, anti-inflammatory, antiviral, antibacterial, and antiseptic agent, mainly in the treatment of the upper respiratory system [14]. The scientific literature reveals the pharmacological properties of thymol and its multiple therapeutic actions against various cardiovascular, neurological, rheumatological, gastrointestinal, metabolic, and malignant diseases at both biochemical and molecular levels [22].

The antimicrobial activity of Thymus species, as well as thymol, has been well studied. In our previous study $[9,10]$, the ethanolic extracts obtained from leaves of various Thymus representatives exhibited intermediate activity against $\beta$-lactamaseproducing Pseudomonas aeruginosa and Salmonella enteritidis strains locally isolated. The effects varied significantly according to the Thymus taxa. It should be noted that the most antimicrobial effective plant against $\beta$-lactamase-producing $P$. aeruginosa was $T h$. alpestris Tausch ex A. Kern., being highly active with the ethanolic extract (mean diameter of inhibition zone was $12.8 \pm 0.8 \mathrm{~mm}$ ). The antibacterial activity of extracts was greatest for Th. alpestris followed by Th. pannonicus All. followed by Th. serpyllum L. and then by Th. pulegioides L. [10]. The ethanolic extract obtained from the leaves of Th. pulegioides were the most effective plant extracts against $S$. enteritidis. The antibacterial activity of extracts was greatest for Th. pulegioides followed by Th. pannonicus followed by Th. alpestris, Th. $\times$ porcii, and then by Th. serpyllum. These plant extracts could be a potential source of new antibacterial agents [9].

Many in vitro studies confirmed the antioxidant properties of thyme extracts $[8$, $11,22,27]$. Many results also clearly suggest that treatment by Thymus extracts in vivo and in vitro prevents organ damage via protection of the antioxidant defense system and scavenge of hydroxyl free radicals by producing phenoxyl radicals, major transient species [22]. For example, the phenolic constituent profiles and the antioxidant, antiproliferative, neuroprotective, anti-aging, and anti-diabetic activities of both Th. pulegioides aqueous decoctions (AD) and hydro-ethanolic extracts (HE) were studied by Taghouti et al. (2018). Rosmarinic acid was the main phenolic compound, accounting for $35.2 \%$ or $47.8 \%$ of total identified phenols in AD or HE, respectively. Furthermore, large amounts of luteolin-O-hexuronide, eriodictyol-O-hexuronide, and chrysoeriol hexoside were found. Both extracts showed significant in vitro antioxidant activity and anti-proliferative activity against Caco-2 cells and reduced hepatotoxicity (HepG2 
cells). In general, both Th. pulegioides extracts showed poor anti-diabetic activity, moderate anti-aging effects and high neuroprotective activity with both $\mathrm{AD}$ and HE extracts, at $0.5 \mathrm{mg} \mathrm{mL}^{-1}$, showing $80 \%$ inhibition of the acetylcholinesterase activity and $94 \%$ inhibition of the tyrosinase activity [27].

Six different assays were employed in the study of Kindl et al. (2015) to evaluate the antioxidant properties of the ethanolic extracts of selected Thymus species growing in Croatia (Th. longicaulis, Th. praecox subsp. polytrichus, Th. pulegioides, Th. serpyllum subsp. serpyllum, Th. striatus, and Th. vulgaris) as well as to elucidate its mode of action. The tested Thymus extracts and pure compounds at different concentrations $(0.4-25 \mu \mathrm{g} / \mathrm{mL})$ significantly inhibited DPPH in a concentration-dependent manner. The activities of plant extracts were 11-28\%, 23-52 \%, and 52-85\% at $1.56 \mu \mathrm{g} / \mathrm{mL}, 3.13 \mu \mathrm{g} / \mathrm{mL}$, and $6.25 \mu \mathrm{g} / \mathrm{mL}$, respectively. At the mentioned concentrations, Th. serpyllum subsp. serpyllum as well as a commercial sample of Th. vulgaris were the least effective [13].

In line with our previous study, we continue to assess the antioxidant potential of four species and one interspecific hybrid of the Thymus genus sampled in the Western part of Ukraine on the equine erythrocytes' model. Therefore, in the present study, the oxidative stress biomarkers [2-thiobarbituric acid reactive substances (TBARS), carbonyl derivatives content of protein oxidative modification, total antioxidant capacity (TAC)], as well as $\mathrm{HCl}$-induced hemolysis in the equine erythrocytes, was used for assessing the antioxidant activity of extract obtained from the leaves of Th. pulegioides in dose $5 \mathrm{mg} / \mathrm{mL}$.

Materials and methods. Collection of Plant Materials. Leaves of Thymus pulegioides L. were collected among grass nearby land parcels (Syvky village, Bilo-

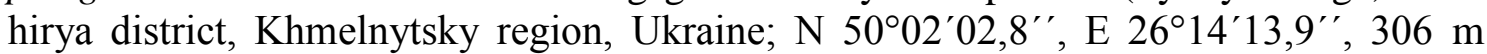
a.s.1.) (Photo 1). Identification of this species was made according to Nachychko (2014, 2015) and Nachychko and Honcharenko (2016) [18-20]. The voucher herbarium specimens of plants used in this study were deposited at the Herbarium of M.G. Kholodny Institute of Botany of the National Academy of Sciences of Ukraine (KW). Plant samples were thoroughly washed to remove all the attached material and used to prepare the extract. This study was carried out during the Scholarship Program supported by The Visegrad Fund in the Department of Zoology and Animal Physiology, Institute of Biology and Earth Sciences, Pomeranian University in Słupsk (Poland).

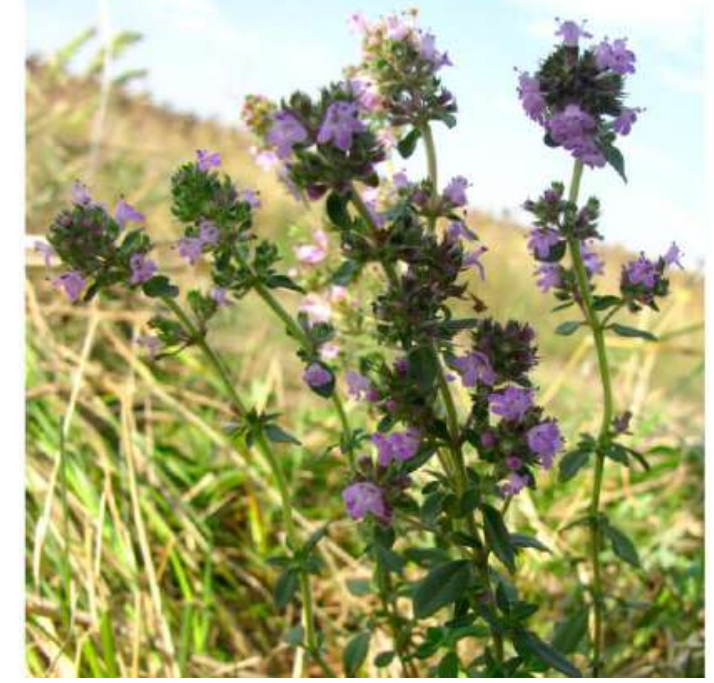
charenko)

Photo 1. Thymus pulegioides plant (Photo: Viktor Nachychko, Vitaliy Hon- 
Preparation of Plant Extract. Freshly collected leaves were washed, weighed, crushed, and homogenized in $0.1 \mathrm{M}$ phosphate buffer ( $\mathrm{pH} 7.4$ ) (in proportion 1:19, w/w) at room temperature. The extracts were then filtered and used for analysis. The extract was stored at $-20^{\circ} \mathrm{C}$ until use.

Horses. Eighteen healthy adult horses from the central Pomeranian region in Po-

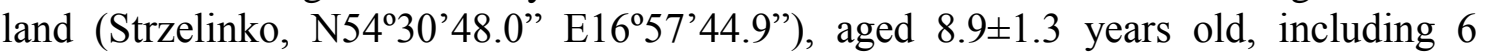
Hucul pony, 5 Thoroughbred horses, 2 Anglo-Arabian horses, and 5 horses of unknown breed, were used in this study. All horses participated in recreational horseback riding. Horses were housed in individual boxes, with feeding (hay and oat) provided twice a day, at 08.00 and $18.00 \mathrm{~h}$, and water available ad libitum. All horses were thoroughly examined clinically and screened for hematological, biochemical, and vital parameters, which were within reference ranges. The females were non-pregnant.

Collection of blood samples. Blood was taken from the jugular vein of the animals in the morning, 90 minutes after feeding, while the horses were in the stables (between 8:30 and 10 AM). Blood was stored in tubes with sodium citrate as the anticoagulant and held on the ice until centrifugation at $3.000 \mathrm{rpm}$ for $5 \mathrm{mins}$ to remove plasma. The pellet of blood was resuspended in $4 \mathrm{mM}$ phosphate buffer ( $\mathrm{pH}$ 7.4). A volume of $0.1 \mathrm{ml}$ of the plant extract was added to $1.9 \mathrm{ml}$ of clean equine erythrocytes. For positive control (phosphate buffer) was used. After incubation of the mixture at $37^{\circ} \mathrm{C}$ for 60 mins with continuous stirring, it was centrifuged at 3,000 rpm for 5 mins. Erythrocyte aliquots were used in the study.

2-Thiobarbituric Acid Reactive Substances (TBARS) assay. The level of lipid peroxidation was determined by quantifying the concentration of 2-thiobarbituric acid reacting substances (TBARS) with the Kamyshnikov (2004) method for determining the malondialdehyde (MDA) concentration [12]. This method is based on the reaction of the degradation of the lipid peroxidation product, MDA, with TBA under high temperature and acidity to generate a colored adduct that is measured spectrophotometrically. The $\mu \mathrm{mol}$ of MDA per $1 \mathrm{~L}$ was calculated using $1.56 \cdot 10^{5} \mathrm{mM}^{-1} \mathrm{~cm}^{-1}$ as the extinction coefficient.

The carbonyl derivatives content of protein oxidative modification (OMP) assay. To evaluate the protective effects of extracts obtained from leaves of Th. pulegioides against free radical-induced protein damage in equine erythrocytes, a carbonyl derivatives content of protein oxidative modification (OMP) assay based on the spectrophotometric measurement of aldehydic and ketonic derivatives in the erythrocyte suspension was performed. The rate of protein oxidative destruction was estimated from the reaction of the resultant carbonyl derivatives of amino acid reaction with 2,4dinitrophenylhydrazine (DNFH) as described by Levine and co-authors (1990) [15] and as modified by Dubinina and co-authors (1995) [5]. DNFH was used for determining carbonyl content in soluble and insoluble proteins. Carbonyl groups were determined spectrophotometrically from the difference in absorbance at $370 \mathrm{~nm}$ (aldehyde derivatives, $\mathrm{OMP}_{370}$ ) and $430 \mathrm{~nm}$ (ketonic derivatives, $\mathrm{OMP}_{430}$ ).

Measurement of Total Antioxidant Capacity (TAC). The TAC level in the sample was estimated by measuring the 2-thiobarbituric acid reactive substances (TBARS) level after Tween 80 oxidation. This level was determined spectrophotometrically at $532 \mathrm{~nm}$ [7]. Sample inhibits the $\mathrm{Fe}^{2+}$ /ascorbate-induced oxidation of Tween 80, resulting in a decrease in the TBARS level. The level of TAC in the sample (\%) was calculated concerning the absorbance of the blank sample.

Assay of Acid Resistance of Erythrocytes. The acid resistance of erythrocytes was measured spectrophotometrically with $0.1 \mathrm{M} \mathrm{HCl} \mathrm{[28].} \mathrm{The} \mathrm{assay} \mathrm{is} \mathrm{based} \mathrm{on} \mathrm{the}$ measuring of the dynamics of erythrocytes disintegration into hemolytic reagent action. 
The time of hemolytic reagent action serves as the measure of erythrocyte resistance. The assay mixture contained $5 \mathrm{~mL}$ of $1 \%$ erythrocyte suspension and $0.05 \mathrm{~mL}$ of $0.1 \mathrm{M}$ $\mathrm{HCl}$. The absorbance was read at $540 \mathrm{~nm}$ every 30 seconds after $\mathrm{HCl}$ addition till the end of hemolysis. The difference of absorbance at the beginning and the end of hemolysis was determined as $100 \%$ (total hemolysis). The disintegration of erythrocytes (\%) at every 30 seconds was expressed as a curve.

Statistical analysis. The mean \pm S.E.M. values were calculated for each group to determine the significance of the intergroup difference. All variables were tested for normal distribution using the Kolmogorov-Smirnov and Lilliefors test ( $p>0.05)$. The significance of differences between the values (significance level, $\mathrm{p}<0.05$ ) was examined using the Mann-Whitney $U$ test [31]. All statistical calculation was performed on separate data from each individual with STATISTICA 8.0 software (StatSoft, Krakow, Poland).

Results and discussion. After incubation of equine erythrocytes with a leaf extract obtained from Th. pulegioides, the aldehydic and ketonic derivatives level, as well as total antioxidant capacity, were non-significantly altered. The Th. pulegioides extract caused to increase in TBARS content as a biomarker of lipid peroxidation in the extracttreated erythrocytes, and these results were statistically significant (by $51.2 \%, \mathrm{p}<0.05$ ). The aldehydic and ketonic derivatives level was non-significantly decreased by $1.2 \%$ and $5.6 \%$ (p>0.05), respectively (Fig. 1).
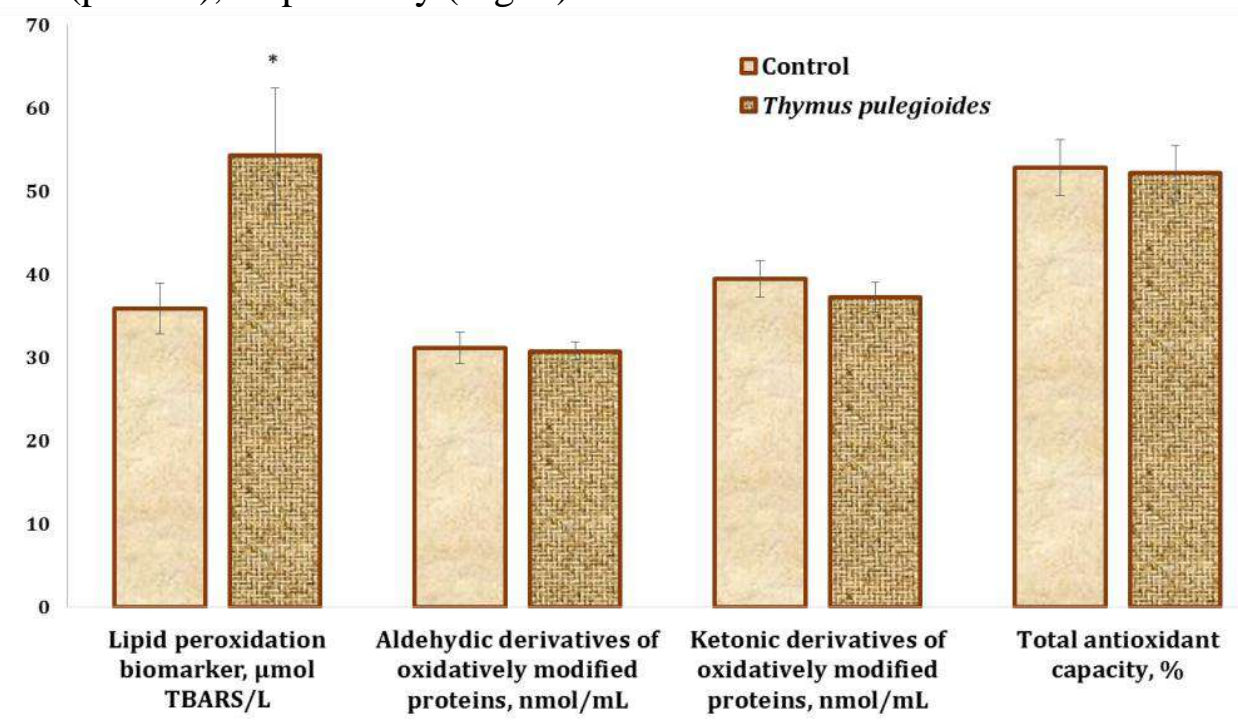

Fig. 1. The TBARS content as biomarker of lipid peroxidation, aldehydic and ketonic derivatives of oxidatively modified proteins, and total antioxidant capacity in the equine erythrocytes suspension after in vitro incubation with leaf extract obtained from Thymus pulegioides $(\mathrm{M} \pm \mathbf{m}, \mathbf{n}=18)$.

*- changes were statistically significant $(\mathrm{p}<0.05)$.

The erythrocytes of mammals represent a good model to evaluate the cytotoxicity of molecules, organic and inorganic, natural or synthetic, by cellular damage measure [23]. Erythrocytes are especially vulnerable since they have no membrane repair and regenerative capacity [29] and red cell damages by free radicals would probably be associated with hemolysis [6]. Therefore, the next purpose of our study was to evaluate the effect of Th. pulegioides extract $(5 \mathrm{mg} / \mathrm{mL})$ on the in vitro $\mathrm{HCl}$-induced hemolysis of the equine erythrocytes (Fig. 2).

In the control group (erythrocyte suspension), erythrocytes incubated with $0,1 \mathrm{M}$ $\mathrm{HCl}$ remained stable and demonstrated slight hemolysis. The maximum level of hemol- 
ysis was $(17.21 \pm 1.32) \%$; the total duration of hemolysis was 12 mins. When Th. pulegioides extract $(5 \mathrm{mg} / \mathrm{mL})$ was added to the erythrocyte suspension, the maximum level of hemolysis occurred after 6.5 mins of incubation with $0.1 \mathrm{M} \mathrm{HCl}$ $(17.27 \pm 1.55) \%$. The total duration of hemolysis after Th. pulegioides extract $(5 \mathrm{mg} / \mathrm{mL})$ incubation was 10.5 mins. Our results showed that $\mathrm{HCl}$-induced hemolysis in a typical time-dependent manner. Therefore, Th. pulegioides extract at a concentration of $5 \mathrm{mg} / \mathrm{mL}$ induced the increase of hemolyzed erythrocytes and caused to decrease in hemolysis duration (Fig. 2).

Many both in vitro and in vivo studies have shown that plants belonging to the Thymus genus possess antioxidant properties. For instance, Afonso and co-authors (2017) have evaluated the phytochemical characterization and the potential antioxidant, anti-inflammatory, and antimicrobial activities of three Thymus species, i.e. Thymus herba-barona, Thymus pseudolanuginosus, and Thymus caespititius, which have been poorly explored. Results of these authors suggested that the T. pseudolanuginosus extract presented the best DPPH radical scavenging ability, a high reducing power, and effectively inhibited the oxidation of $\beta$-carotene. The extracts also showed NO scavenging activity close to that of ascorbic acid, and thus might be useful as anti-inflammatory agents. Also, they exhibited antibacterial activity against gram-negative and grampositive bacteria. Staphylococcus aureus strains were the most sensitive bacteria to thyme extracts, with minimum inhibitory concentration and minimum bactericidal concentration values in the range of $0.6-3.5 \mathrm{mg} / \mathrm{mL}$ [2].

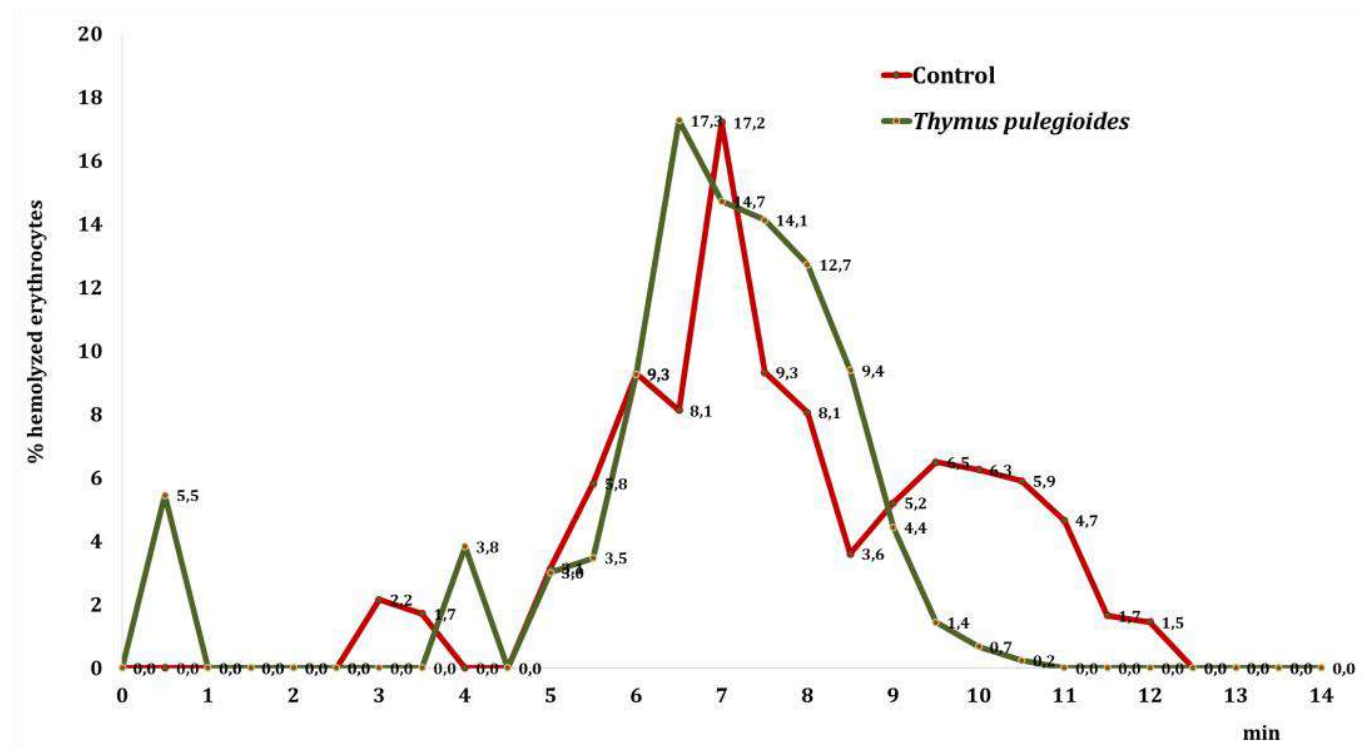

Fig. 2. Effect of Th. pulegioides extract $(5 \mathrm{mg} / \mathrm{mL})$ on the $\mathrm{HCl}$-induced hemolysis in vitro of the equine erythrocytes $(M \pm m, n=18)$.

On the other hand, Butt and co-authors (2019) have evaluated the anti-oxidant and anti-proliferative potential of Thymoquinone extracted from the essential oil of indigenous herbs of Nigella sativa and Thymus vulgaris [3]. Cell proliferation of HeLa cancer significantly decreased with a dose-response manner $(\mathrm{p}<0.01)$, showing the highest cell death in a high concentration of Thymoquinone. Inhibitory concentration 50 $\left(\mathrm{IC}_{50}\right)$ of cancer cell line treated with Nigella sativa oil was $0.5 \mu \mathrm{M}$ and Thymus vulgaris was $18 \mu \mathrm{M}$ compared to standard Thymoquinone, showing Inhibitory concentration $\left(\mathrm{IC}_{50}\right)$ of $6 \mu \mathrm{M}$. Researchers concluded that both Nigella sativa and Thymus vulgaris were found to be the best source of Thymoquinone as chemotherapeutic drugs expressed potent anti-oxidant and anti-proliferative activities [3]. 
The antioxidant and acetylcholinesterase (AChE) inhibitory activities of the ethanolic extracts of six selected Thymus species growing in Croatia ( $T$. longicaulis, $T$. praecox subsp. polytrichus, T. pulegioides, T. serpyllum subsp. serpyllum, T. striatus, and T. vulgaris) were evaluated by Kindl and co-authors (2015) [13]. Antioxidant effectiveness was assessed using six different assays, in comparison with rosmarinic acid, luteolin, and reference antioxidants. All tested Thymus extracts possessed DPPH and nitric oxide free radical scavenging activities, strong reducing properties, ferrous ion chelating activity, ability to inhibit lipid peroxidation, and high total antioxidant capacities. All tested extracts showed anti-AChE activity in a dose-dependent manner. Additionally, the contents of total hydroxycinnamic derivatives, flavonoids, and tannins in dried plant samples were also determined by Kindl and co-authors (2015) [13]. Thus, Thymus species is a rich source of natural antioxidants and AChE inhibitors that could be useful in preventing and treating Alzheimer's disease and other neurodegenerative disorders.

Also, the in vitro cultures of many Thymus species represent a promising alternative for the production of valuable natural antioxidants. The phenolic metabolites and antioxidant activities of Thymus lotocephalus G. López \& R. Morales wild plants and in vitro cultures using different extraction solvents were studied by Costa and co-authors (2012). HPLC-DAD analysis allowed the identification and quantification of phenolic (caffeic and rosmarinic acids) and flavones (luteolin and apigenin) in extracts from both sources. The in vitro cultures accumulated large amounts of rosmarinic acid. However, extracts from both sources were able to neutralize free radicals in different test systems (TEAC and ORAC assays), form complexes with $\mathrm{Fe}^{2+}$, and protect mouse brains against $\mathrm{Fe}^{2+}$-induced lipid peroxidation. The solvent significantly influenced the phenolic content and antioxidant activity of the extracts, water/ethanol being the most efficient for the extraction of antioxidant phytochemicals [4].

Thymus daenensis has also a potential herbal medicine that should be considered as an antibacterial and antioxidant with very low toxicity. Saidi and co-authors (2016) have investigated the antibacterial activity and subsequently, determine the antioxidant activity of Thymus daenensis. The association between phenolic compound and antioxidant activity was found for the ABTS + method (43.52\%) in the lowest level, while, for FRAD and DPPH $\cdot$ methods the opposite story occurred $(70.5 \%$ correlation for DPPH. and $50.9 \%$ for FRAD) [24].

Thymol also increases the activity of endogenous antioxidant enzymes, such as superoxide dismutase, catalase, glutathione peroxidase, glutathione-S-transferase, and the level of other non-enzymatic antioxidants such as vitamin C, vitamin E, and reduced glutathione [17], and thereby the total antioxidant status in vivo [30]. In our previous study, the oxidative stress biomarkers [2-thiobarbituric acid reactive substances (TBARS), carbonyl derivatives content of protein oxidative modification, total antioxidant capacity (TAC)], as well as $\mathrm{HCl}$-induced hemolysis in the equine erythrocytes, was used for assessing the antioxidant activity of extract obtained from the leaves of Th. $\times$ porcii Borbás (a hybrid between Th. pannonicus and Th. pulegioides) was studied. The aldehydic and ketonic derivatives level, as well as total antioxidant capacity, was nonsignificantly altered after in vitro incubation with an extract obtained from leaves of Th. $x$ porcii. The Th. $x$ porcii extract caused to increase in TBARS content as a biomarker of lipid peroxidation in the extract-treated erythrocytes, and these results were statistically significant. Total antioxidant capacity was non-significantly increased. When Th. x porcii extract $(5 \mathrm{mg} / \mathrm{mL})$ was added to the erythrocyte suspension, the maximum level of hemolysis occurred after $8.5 \mathrm{mins}$ of incubation with $0.1 \mathrm{M} \mathrm{HCl}$ $(17.91 \pm 1.87 \%)$. The total duration of hemolysis after Th. $x$ porcii extract $(5 \mathrm{mg} / \mathrm{mL})$ 
incubation was 11.5 mins. Our results showed that HCl-induced hemolysis in a typical time-dependent manner. the extract obtained from leaves of Th. x porcii $(5 \mathrm{mg} / \mathrm{mL})$ has a mild cytotoxic activity on the equine erythrocytes increasing the level of lipid peroxidation biomarker and hemolysis rate. Investigation of the mechanism of action revealed that this extract has hemolytic activity. Therefore, Th. x porcii extract at a concentration of $5 \mathrm{mg} / \mathrm{mL}$ induced the increase of hemolyzed erythrocytes and caused to decrease in hemolysis duration [11]. Also, lipid peroxidation biomarker, aldehydic and ketonic derivatives of oxidatively modified proteins, total antioxidant capacity was nonsignificantly altered after in vitro incubation with an extract obtained from Thymus serpyllum L. emend. Mill. [8]. Screening of Thymus species for other biological activities including antioxidant activities is essential and may be effective for searching the preventive agents in the pathogenesis of some metabolic diseases.

The noteworthy effects of thymol are primarily attributed to its antiinflammatory (via inhibiting recruitment of cytokines and chemokines), antioxidant (via scavenging of free radicals, enhancing the endogenous enzymatic and non-enzymatic antioxidants, and chelation of metal ions), antihyperlipidemic (via increasing the levels of high-density lipoprotein cholesterol and decreasing the levels of low-density lipoprotein cholesterol and low-density lipoprotein cholesterol in the circulation and membrane stabilization) (via maintaining ionic homeostasis) effects [22]. Thymol attenuates inflammation by inhibiting the release of lysosomal enzymes and downregulates the expressions of pro-inflammatory cytokines by its potent anti-inflammatory effect. The study conducted by Nagoor Meeran and co-authors (2015) revealed the protective effects of thymol on inflammation in isoproterenol (ISO) induced myocardial infarcted rats. ISO-induced myocardial infarcted rats showed increased levels of serum cardiac troponin-T, high sensitive C-reactive protein (hsCRP), lysosomal thiobarbituric acid reactive substances (TBARS), and elevated ST-segments. Also, the activities of lysosomal enzymes such as $\beta$-glucuronidase, $\beta$-galactosidase, cathepsin-B, and $\mathrm{D}$, the stimulators of inflammatory mediators were increased in the serum and heart of ISO induced myocardial infarcted rats. Furthermore, ISO up-regulates the expressions of proinflammatory cytokines such as tumor necrosis factor- $\alpha$ (TNF- $\alpha$ ), interleukin-6 (IL-6), and interleukin-1 $\beta$ (IL-1 $\beta$ ) genes in the myocardium of rats analyzed by reverse transcription-polymerase chain reaction (RT-PCR). Pre and co-treatment with thymol (7.5 mg/kg body weight) near normalized the levels of lysosomal TBARS, activities of serum and heart lysosomal enzymes, and downregulates the expressions of proinflammatory cytokines in the myocardium of ISO induced myocardial infarcted rats [21].

The results of Youdim and Deans (2000) highlight the potential benefit of thyme oil as a dietary antioxidant. These researchers have evaluated changes in antioxidant enzyme activity and the phospholipid fatty acid composition of the aging rat brain and tested whether dietary supplementation with thyme oil or thymol could provide beneficial effects. There were significant declines in superoxide dismutase and glutathione peroxidase activities and the total antioxidant status in the untreated rats with age, while thyme-oil- and thymol-fed rats maintained significantly higher antioxidant enzyme activities and total antioxidant status. The proportions of 18:2n-6, 20:1n-9, 22:4n-6, and $22: 5 n-3$ in the brain phospholipids resulting from all three dietary treatments were significantly higher in 28-month-old rats than in 7-month-old rats. Only 20:1n-9 levels in 28-month-old thyme-oil- and thymol-treated rats were significantly higher than in the age-matched control. The proportion of 22:6n-3 in brain phospholipids, which declined with age in control rats, was also significantly higher in rats given either supplement. 
This latter finding is particularly important as optimum levels of 22:6n-3 are required for normal brain function [30].

Significant antioxidant activity of plants belonging to the Thymus genus is correlated with their polyphenol levels. For instance, the polyphenol compositions of Thymus $\times$ citriodorus and Thymus vulgaris extracts as obtained by exhaustive hydroethanolic (HE) extraction and aqueous decoction (AD) were compared in the study of Taghouti and co-authors (2020) [26]. Also, their compositions and bioactivities were compared to those of Thymus pulegioides and Thymus mastichina, grown under the same edaphoclimatic conditions, and Thymus carnosus. Rosmarinic acid was the most abundant polyphenol followed by luteolin-hexuronide, salvianolic acids I, and K. Cluster analysis suggests a similarity of the polyphenol composition of $T$. citriodorus and $T$. vulgaris. The same being observed for the higher anti-proliferative activity/cytotoxicity of $\mathrm{HE}$ extracts on Caco-2 and HepG2 cells as compared to AD extracts. A significant association between the total phenolic compounds with the anti-proliferative activity, for both cell lines, was observed. Results of Taghouti and co-authors (2020) supported the importance of salvianolic acid levels in Thymus extracts and their in vitro antiproliferative/cytotoxic activities [26].

Conclusions. The extract obtained from leaves of Th. pulegioides $(5 \mathrm{mg} / \mathrm{mL})$ has a mild cytotoxic activity on the equine erythrocytes increasing the level of lipid peroxidation biomarker and hemolysis rate. The investigation also revealed that this extract exhibited hemolytic activity. These findings suggest the use of Th. pulegioides extract in dose $5 \mathrm{mg} / \mathrm{mL}$ as a source of prooxidant compounds and warrant further studies to evaluate their therapeutic potential. The aldehydic and ketonic derivatives level, as well as total antioxidant capacity, was non-significantly altered after in vitro incubation with an extract obtained from leaves of Th. pulegioides. Screening of Thymus species for other biological activities including antioxidant activities is essential and may be effective for searching the preventive agents in the pathogenesis of some diseases as well as prevention and treatment of some disorders in medicine and veterinary.

\section{References}

1. Afonso, A. F., Pereira, O. R., \& Cardoso, S. M. (2020). Health-Promoting Effects of Thymus Phenolic-Rich Extracts: Antioxidant, Anti-Inflammatory and Anti$\begin{array}{lllll}\text { tumoral Properties. } & \text { Antioxidants } & \text { (Basel), } & 9 & \text { (9), }\end{array}$ https://doi.org/10.3390/antiox9090814.

2. Afonso, A. F., Pereira, O. R., Neto, R. T., Silva, A. M., \& Cardoso, S. M. (2017). Health-Promoting Effects of Thymus herba-barona, Thymus pseudolanuginosus, and Thymus caespititius Decoctions. Int. J. Mol. Sci., 18 (9), 1879. https://doi.org/10.3390/ijms18091879.

3. Butt, A. S., Nisar, N., Mughal, T. A., Ghani, N., \& Altaf, I. (2019). Antioxidative and anti-proliferative activities of extracted phytochemical compound thymoquinone. J. Pak. Med. Assoc., 69 (10), 1479-1485.

4. Costa, P., Gonçalves, S., Valentão, P., Andrade, P. B., Coelho, N., \& Romano, A. (2012). Thymus lotocephalus wild plants and in vitro cultures produce different profiles of phenolic compounds with antioxidant activity. Food Chem., 135 (3), 1253-1260. https://doi.org/10.1016/j.foodchem.2012.05.072.

5. Dubinina, E. E., Burmistrov, S. O., Khodov, D. A., \& Porotov, I. G. (1995). Okislitel'naia modifikatsiia belkov syvorotki krovi cheloveka, metod ee opredeleniia [Oxidative modification of human serum proteins. A method of determining it]. Vopr. Med. Khim., 41 (1), 24-26. [in Russian]. 
6. Farag, M. R., Alagawany, M. (2018). Erythrocytes as a biological model for screening of xenobiotics toxicity. Chem. Biol. Interact., 279, 73-83. https://doi.org/10.1016/j.cbi.2017.11.007.

7. Galaktionova, L. P., Molchanov, A. V., El'chaninova, S. A., \& Varshavskiı̌, B. Ia. (1998). Sostoianie perekisnogo okisleniia u bol'nykh s iazvennoŭ bolezn'iu zheludka i dvenadtsatiperstnoî kishki [Lipid peroxidation in patients with gastric and duodenal peptic ulcers]. Klin. Lab. Diagn., (6), 10-14. [in Russian].

8. Honcharenko, V., Tkachenko, H., Nachychko, V., Prokopiv, A., \& Osadowski, Z. (2018). Oxidative stress biomarkers in the equine erythrocyte suspension after in vitro incubation with leaf extract obtained from Thymus serpyllum L. emend. Mill. (Lamiaceae). Agrobiodiversity for Improving Nutrition, Health and Life Quality, (2): 201-211. https://doi.org/10.15414/agrobiodiversity.2018.2585-8246.201-211.

9. Honcharenko, V., Tkachenko, H., Nachychko, V., Prokopiv, A., \& Osadowski, Z. (2018). The antibacterial activities of some Thymus (Lamiaceae) representatives against Salmonella enteriditis strain locally isolated. Agrobiodiversity for Improving Nutrition, Health, and Life Quality, (2), 212-222. https://doi.org/10.15414/agrobiodiversity.2018.2585-8246.212-222

10. Honcharenko, V., Tkachenko, H., Osadowski, Z., Nachychko, V., \& Prokopiv, A. (2018). The antibacterial activities of ethanolic extracts obtained from leaves of some Thymus (Lamiaceae) representatives against $\beta$-lactamase producing Pseudomonas aeruginosa strain. Stupskie Prace Biologiczne, 15, 59-78.

11. Honcharenko, V., Tkachenko, H., Prokopiv, A., Nachychko, V., Kurhaluk, N., \& Osadowski, Z. (2019). Oxidative stress biomarkers in the equine erythrocytes after In Vitro treated with leaf extract obtained from Thymus $\times$ porcii Borbás (Lamiaceae). Agrobiodiversity for Improving Nutrition, Health, and Life Quality, (3), 382-393. https://doi.org/10.15414/agrobiodiversity.2019.2585-8246.382-393.

12. Kamyshnikov, V.S. (2004). A reference book on the clinic and biochemical researches and laboratory diagnostics. MEDpress-inform, Moscow.

13. Kindl, M., Blažeković, B., Bucar, F., \& Vladimir-Knežević, S. (2015). Antioxidant and Anticholinesterase Potential of Six Thymus Species. Evid. Based Complement. Alternat. Med., 2015, 403950. https://doi.org/10.1155/2015/403950.

14. Kowalczyk, A., Przychodna, M., Sopata, S., Bodalska, A., \& Fecka, I. (2020). Thymol and Thyme Essential Oil-New Insights into Selected Therapeutic Applications. Molecules, 25 (18), 4125. https://doi.org/10.3390/molecules25184125.

15. Levine, R. L., Garland, D., Oliver, C. N., Amici, A., Climent, I., Lenz, A. G., Ahn, B. W., Shaltiel, S., \& Stadtman, E. R. (1990). Determination of carbonyl content in oxidatively modified proteins. Methods Enzymol., 186, 464-478. https://doi.org/10.1016/0076-6879(90)86141-h.

16. Li, X., He, T., Wang, X., Shen, M., Yan, X., Fan, S., Wang, L., Wang, X., Xu, X., Sui, H., \& She, G. (2019). Traditional Uses, Chemical Constituents and Biological Activities of Plants from the Genus Thymus. Chem. Biodivers., 16 (9), e1900254. https://doi.org/10.1002/cbdv.201900254.

17. Meeran, M. F., Prince, P. S. (2012). Protective effects of thymol on altered plasma lipid peroxidation and nonenzymic antioxidants in isoproterenol-induced myocardial infarcted rats. J. Biochem. Mol. Toxicol., 26(9), 368-373. https://doi.org/10.1002/jbt.21431.

18. Nachychko, V. (2014). The genus Thymus L. (Labiatae Juss.) in the Ukrainian Carpathians' flora: systematics and taxonomic problems. Visnyk of Lviv University. Biological Series, 64, 159-169 [in Ukrainian]. 
19. Nachychko, V. O. (2015). Diagnostic features of representatives of Thymus sect. Serpyllum and T. sect. Marginati (Lamiaceae) and guidance for their herborization. The Journal of V. N. Karazin Kharkiv National University. Series: Biology, 25, 77-89. [In Ukrainian].

20. Nachychko, V. O., Honcharenko, V. I. (2016). Hybrids of Thymus L. (Lamiaceae) genus in flora of the western regions of Ukraine: taxonomic composition and distribution. Studia Biologica, 10 (1), 163-186. [in Ukrainian].

21. Nagoor Meeran, M. F., Jagadeesh, G. S., Selvaraj, P. (2015). Thymol attenuates inflammation in isoproterenol induced myocardial infarcted rats by inhibiting the release of lysosomal enzymes and downregulating the expressions of proinflammatory cytokines. Eur. $\quad J$. Pharmacol., $754, \quad$ 153-161. https://doi.org/10.1016/j.ejphar.2015.02.028.

22. Nagoor Meeran, M. F., Javed, H., Al Taee, H., Azimullah, S., \& Ojha, S. K. (2017). Pharmacological Properties and Molecular Mechanisms of Thymol: Prospects for Its Therapeutic Potential and Pharmaceutical Development. Front. Pharmacol., 8, 380. https://doi.org/10.3389/fphar.2017.00380.

23. Pagano, M., Faggio, C. (2015). The use of erythrocyte fragility to assess xenobiotic cytotoxicity. Cell Biochem. Funct., 33(6), 351-355. https://doi.org/10.1002/cbf.3135.

24. Saidi, M., Sadeghifard, N., Kazemian, H., Sekawi, Z., Badakhsh, B., Friadian, S., \& Ghafourian, S. (2016). Ex Vivo Evaluation of Thymus daenensis as an Antioxidant and Antibacterial Medicinal Herb. Drug Res. (Stuttg.), 66 (12), 657-659. https://doi.org/10.1055/s-0042-113457.

25. Salehi, B., Mishra, A. P., Shukla, I., Sharifi-Rad, M., Contreras, M. D. M., Segura-Carretero, A., Fathi, H., Nasrabadi, N. N., Kobarfard, F., \& Sharifi-Rad, J. (2018). Thymol, thyme, and other plant sources: Health and potential uses. Phytother. Res., 32(9), 1688-1706. https://doi.org/10.1002/ptr.6109.

26. Taghouti, M., Martins-Gomes, C., Félix, L. M., Schäfer, J., Santos, J. A., Bunzel, M., Nunes, F. M., \& Silva, A. M. (2020). Polyphenol composition and biological activity of Thymus citriodorus and Thymus vulgaris: Comparison with endemic Iberian Thymus species. Food Chem., 331, 127362. https://doi.org/10.1016/j.foodchem.2020.127362.

27. Taghouti, M., Martins-Gomes, C., Schäfer, J., Félix, L. M., Santos, J. A., Bunzel, M., Nunes, F. M., \& Silva, A. M. (2018). Thymus pulegioides L. as a rich source of antioxidant, anti-proliferative and neuroprotective phenolic compounds. Food Funct., 9(7), 3617-3629. https://doi.org/10.1039/c8fo00456k.

28. Terskov, I. A., Gitelson, I. I. (1957). Method of chemical (acid) erythrograms. Biofizika, 2, 259-266.

29. Webster, N. R., Toothill, C. (1987). Inorganic phosphate transport across the red blood cell membrane: the effect of exposure to hyperoxia. Clin. Chim. Acta, 167(3), 259-265. https://doi.org/10.1016/0009-8981(87)90345-7.

30. Youdim, K. A., Deans, S. G. (2000). Effect of thyme oil and thymol dietary supplementation on the antioxidant status and fatty acid composition of the ageing rat brain. Br. J. Nutr., 83 (1), 87-93.

31. Zar, J. H. (1999). Biostatistical Analysis. $4^{\text {th }}$ ed., Prentice Hall Inc., New Jersey. 
ОЦЕНКА БИОМАРКЕРОВ ОКИСЛИТЕЛЬНОГО СТРЕССА ЭРИТРОЦИТАХ ЛОШАДЕЙ ПОСЛЕ IN VITRО ОБРАБОТКИ ЭКСТРАКТОМ, ПОЛУЧЕННЫМ ИЗ ЛИСТЬЕВ THYMUS PULEGIOIDES L. (LAMIACEAE)

Ткаченко Г., Кургалюк Н., Институт биологии и наук о Земле Поморской академии в Слупске, Польша

Гончаренко В., Начичко В., Прокопив А., Национальный университет имени Ивана Франко, Львов, Украина

Аксенов Е., Институт жсивотноводства НААН, Харьков, Украина

В соответствии с нашим предыдущчими исследованиями, мы продолжили оценку антиоксидантного потенцииала четырех видов и одного межвидового гибрида рода Thyтия, отобранных в западной части Украины на модели эритрочитов лошадей. В настоящем исследовании биомаркеры окислительного стресса [вещества, реагирующие с 2-тиобарбитуровой кислотой (ТБК-продукты), содержание карбонильных производных окислительно модифицированных белков, общая антиоксидантная активность (ТАC)], а также индуцииованный $\mathrm{HCl}$ гемолиз в эритроциттах лошадей, использовали для оиенки антиоксидантной активности экстракта, полученного из листьев Thyтиs pulegioides в дозе 5 мг/мл. Листья Th. pulegioides были собраны среди трав около земельных участков (с. Сывки Белогорского района Хмельницкой области, Украина; N5002'02,8'", E26 ${ }^{\circ} 4^{\prime} 13,9^{\prime \prime}, 306$ м над у.м.). В исследовании использовали аликвоть эритрочитов лошадей. Для положительного контроля использовали фосфатный буфер (рН 7,4). После инкубации смеси при $37{ }^{\circ} \mathrm{C}$ в течение 60 мин при непрерывном перемешивании образиь использовали для биохимических анализов. Результать настоящего исследования показали, что экстракт, полученный из листьев Th. pulegioides (5 мг/мл) обладает умеренной изитотоксической активностью в суспензии эритроиитов лошадей, повышая уровень биомаркера перекисного окисления липидов и скорость гемолиза. Исследование также показало, что этот экстракт проявлял гемолитическую активность. Эти данные предполагают использование Th. pulegioides в дозе 5 мг/мл в качестве источника прооксидантных соединений и требуют дальнейших исследований для оценки их терапевтического потенциала. Уровень альдегидных и кетоновых производных, а также общая антиоксидантная активность существенно не изменились после инкубаиии in vitro с экстрактом, полученным из листьев Th. pulegioides. Скрининг различных видов тимьяна относительно проявления других видов биологической активности, включая антиоксидантную, имеет важное значение и может быть эффективным для поиска профилактических агентов в патогенезе некоторых заболеваний, а также для профилактики и лечения некоторых нарушений в медицине и ветеринарии.

Ключевые слова: Thymиs pulegioides L., экстракт листьев, эритроцитыь лошадей, перекисное окисление липидов, окислительно модифицированные белки, общая антиоксидантная способность, гемолиз

ОЦІНКА БІОМАРКЕРІВ ОКИСНОГО СТРЕСУ В ЕРИТРОЦИТАХ КОНЕЙ ПIСЛЯ IN VITRO ОБРОБКИ ЕКСТРАКТОМ, ОТРИМАНИМ 3 ЛИСТЯ ТНYMUS PULEGIOIDES L. (LAMIACEAE)

Ткаченко Г., Кургалюк Н., Інститут біології та наук про Землю, Поморська Академія в Слупську, Польща.

Гончаренко В., Начичко В., Прокопів А., Начіональний університет імені Івана Франка, Львів, Украӥна.

Аксьонов С., Інститут тваринництва НААН, Харків, Украӥна 
Згідно до наших попередніх досліджень, ми продовжуємо оиінювати антиоксидантний потенціал чотирьох видів $i$ одного міжвидового гібриду роду Thyтия, відібраних в західній частині України на моделі еритрочитів коней. Таким чином, в цьому дослідженні біомаркери окисного стресу [речовини, щьо реагують з 2-тіобарбітурової кислотою (ТБК-продукти), вміст карбонільних похідних окиснювально модифікованих білків, загальна антиоксидантна активність (ТАC)], а також HCl-індукований гемоліз в еритроциттах коней, використовували для оцінки антиоксидантної активності екстракту, отриманого 3 листя Thymиs pulegioides в дозі 5 мг/мл. Листя Th. pulegioides були зібрані серед трав близько земельних ділянок (с. Сивки Білогірського району Хмельницької області, Україна; N 5002'02,8', E 2614'13,9", 306 м р.м.). У дослідженні використовували аліквоти еритроцитів коней. Для позитивного контролю використовували фосфатний буфер (pH 7,4). Після інкубаиї суміші при $37{ }^{\circ} \mathrm{C}$ впродовж 60 хв при безперервному перемішуванні зразки використовували для біохімічних аналізів. Результати иього дослідження показали, що екстракт, отриманий $з$ листя Th. pulegioides (5 мг/мл) володіють помірною иитотоксичною активністю щодо еритрочитів коней, підвищуючи рівень біомаркерів перекисного окиснення ліпідів і швидкість гемолізу. Дослідження також показало, щуо ичей екстракт виявляв гемолітичну активність. Ці дані вимагають подальших досліджень для оцінки терапевтичного потенціалу Th. pulegioides. Рівень альдегідних і кетонових похідних, а також загальна антиоксидантна активність істотно не змінилися після інкубаиї in vitro з екстрактом, отриманим з листя Th. pulegioides. Скринінг різних видів чебрецюю з метою виявлення інших видів біологічної активності, включаючи антиоксидантну активність, має важливе значення $i$ може бути ефективним для пошуку профілактичних агентів в патогенезі деяких захворювань, а також для профілактики і лікування порушень в медицині і ветериHapiï.

Ключові слова: Thymиs pulegioides L., екстракт листя, еритрочити коней, перекисне окиснення ліпідів, окиснювально модифіковані білки, загальна антиоксидантна активность, гемоліз

УДК 636.2.034.082.26

DOI 10.32900/2312-8402-2021-125-59-68

\title{
ПРОДУКТИВНІСТЬ ТА ВІДТВОРЮВАЛЬНА ЗДАТНІСТЬ КРОСБРЕДНИХ КОРІВ-ПЕРВІСТОК
}

\author{
Адмін О. С., к. с.-Г. н., с. н. с., \\ https://orcid.org/0000-0002-5070-8926 \\ Адміна Н. Г., к. с.-г. Н., \\ https://orcid.org/0000-0001-5224-2640 \\ Філіпенко І. Д., асп., \\ Інститут тваринництва НААН
}

У статті наведено результати досліджень відтворювальної здатності, збереженості та середньодобових надоӥв корів-первісток украӥнськоӥ червонорябої молочної породи, отриманих від монбельярдських $і$ голмтинських бугаївплідників у ДП ДГ „Гонтарівка” Харківської області. 